\title{
PANSTEATITIS OF UNKNOWN ETIOLOGY ASSOCIATED WITH LARGE-SCALE NILE CROCODILE (CROCODYLUS NILOTICUS) MORTALITY IN KRUGER NATIONAL PARK, SOUTH AFRICA: PATHOLOGIC FINDINGS
}

\author{
Emily P. Lane, B.V.Sc., M. Phil., Dipl. A.C.V.P., Fritz W. Huchzermeyer, Dr. med. vet., Ph.D., Danny \\ Govender, B.V.Sc., M.Sc., Roy G. Bengis, B.V.Sc. M.Sc., Ph.D., Peter E. Buss, B.V.Sc., M. med. vet., \\ Markus Hofmeyr, B.V.Sc., Jan G. Myburgh, B.V.Sc., M. med. vet., Johan C. A. Steyl, B.V.Sc., M.Sc., \\ Daniel J. Pienaar, B.Sc. Honours, M.Sc., and Antoinette Kotze, B.Sc. Honours, Ph.D.
}

\begin{abstract}
Annual mortality events in Nile crocodiles (Crocodylus niloticus) in the Olifants River Gorge in Kruger National Park, South Africa, were experienced between 2008 and 2012, during which at least 216 crocodiles died. Live crocodiles were lethargic. Necropsy examination of 56 affected crocodiles showed dark yellow-brown firm nodules in both somatic fat and the abdominal fat body. In all of the 11 crocodiles submitted for histology, degenerative, necrotic, and inflammatory changes supported a diagnosis of steatitis in both fat types. Crocodiles are apex predators in this anthropogenically changed aquatic ecosystem that is used by humans upstream and downstream from the park for domestic, agricultural, fishing, and recreational purposes. This pathologic review of pansteatitis in crocodiles in the Olifants River system was part of a broad multidisciplinary research program. To date, no definitive causative agent has been identified. Epidemiologic evidence suggests that this event may have been a one-time event with long-standing repercussions on the health of the crocodiles. Pathologic findings are rarely documented in wild crocodilians. This study also reports on other conditions, including the presence of coccidian oocysts, capillarid and filaroid nematodes, digenetic trematodes, and pentastomes.
\end{abstract}

Key words: Coccidia, Crocodylus niloticus, helminths, Nile crocodile, Olifants Gorge, pansteatitis, pentastomes.

\section{INTRODUCTION}

Pansteatitis is a nutritional disorder affecting mammals, ${ }^{4-9,13,14,16,22,33,34,41,42,52,57}$ crocodilians, ${ }^{12,26,29,36,39,45,51,62}$ chelonians, ${ }^{43}$ fish,,${ }^{17,23,24,44,51,56}$ and piscivorus birds ${ }^{48,53,54,60}$ that is characterized by inflammation and necrosis of adipose tissue and the resultant deposition of lipofuscin and ceroid pigment in fat stores, kidney, spleen, and liver. Affected fat is nodular to diffusely firm yellowbrown instead of pale glistening yellow or white. $5,6,8,16,26,41,55$ The pathogenesis is uncertain, but dietary factors are commonly implicated, particularly the balance between dietary polyunsaturated fatty acids and tissue antioxidants concentration. ${ }^{8}$ Panstea-

From the Research and Scientific Services Department, National Zoological Gardens of South Africa, P.O. Box 754, Pretoria 0001, South Africa (Kotze, Lane); Department of Paraclinical Sciences, Faculty of Veterinary Science, University of Pretoria, Private Bag X 04, Onderstepoort 0110, South Africa (Govender, Huchzermeyer, Myburgh, Steyl); SANParks, Scientific Services, Private Bag X402, Skukuza 1350, South Africa (Buss, Govender, Hofmeyr, Pienaar); State Veterinary Services, P.O. Box 12, Skukuza 1350, South Africa (Bengis); and Genetics Department, University of the Free State, P.O. Box 339, Bloemfontein 9300, South Africa (Kotze). Correspondence should be directed to Dr. Lane (emily@nzg.ac.za). titis is commonly associated with ingestion of high levels of dietary unsaturated fatty acids that may have become oxidized through prolonged storage, freezing, or exposure to environmental heat. ${ }^{6,38,53}$ Selenium $^{13}$ and vitamin $\mathrm{E}$ deficiency, ${ }^{5,7,9,14,21,33,34,38,45,53}$ or both, are also commonly implicated. Vitamin $\mathrm{E}$ functions together with selenium and ascorbic acid in the enzymes glutathione peroxidase and superoxide dismutase to limit oxidative damage due to polyunsaturated fatty acid peroxidation. Glutathione peroxides also are also involved in the maintenance of normal permeability of capillaries and heart muscle. ${ }^{21}$ Selenium also protects against mercury, cobalt, and silver toxicity. ${ }^{37}$ However, because cases are recorded where the diet is not rancid and neither vitamin E nor selenium is deficient, ${ }^{14,49}$ the pathogenesis is likely multifactorial. Intestinal or pancreatic disease may affect nutrient absorption, ${ }^{6,21,34,37}$ and ill-defined "stress" factors, including changes of diet, physical activity, hypothermia, and concurrent intoxications, $, 48,54,56,57$ may affect nutrient and oxidant requirements.

The Nile crocodile (Crocodylus niloticus) is a large reptilian apex predator of freshwater systems throughout Africa. It is considered to be threatened in some parts of its range, ${ }^{32}$ with all trade in live crocodile as well as their skins, meat, and other products subject to the Convention on 


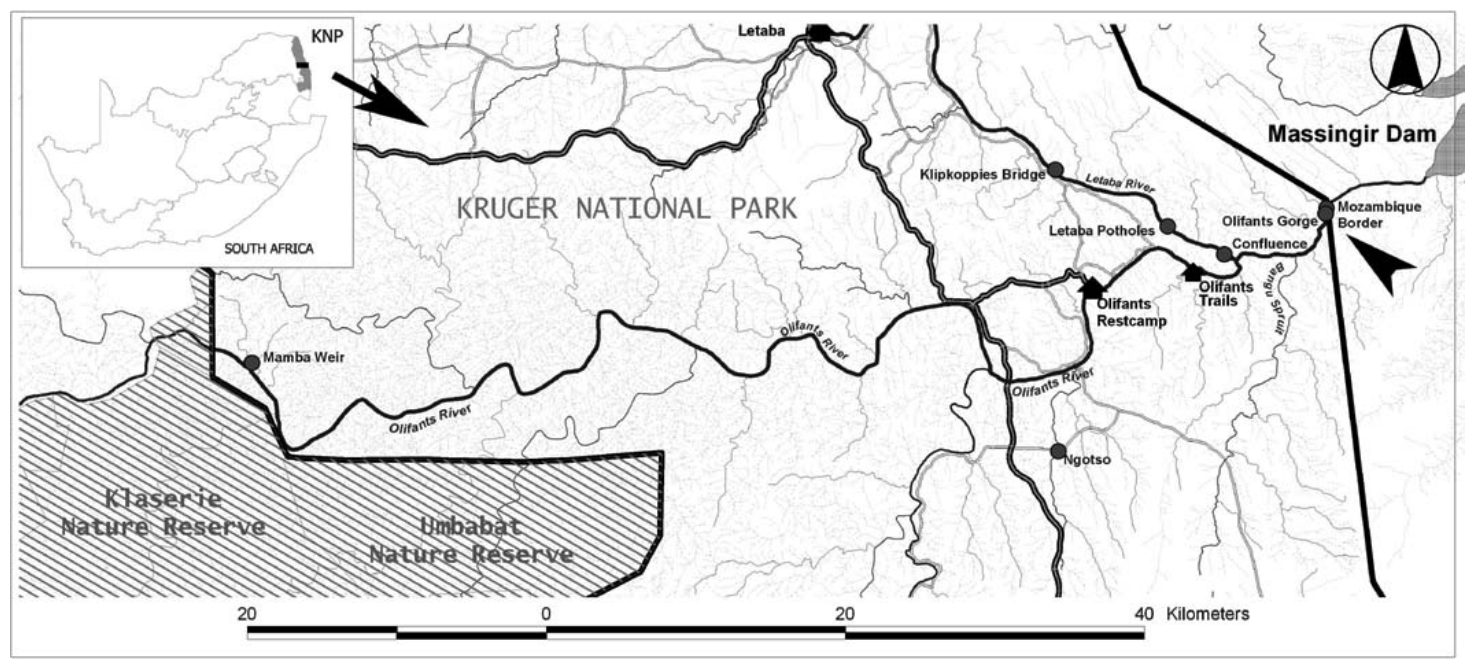

Figure 1. Map showing the Olifants Gorge (arrowhead) in Kruger National Park, South Africa, where crocodile mortalities occurred between 2008 and 2012.

International Trade in Endangered Species of Wild Fauna and Flora (CITES) Appendix 1 regulations. Populations are under threat due to removal of crocodiles from areas close to human habitation, river pollution, and altered riverine habitats by dams and irrigation schemes. ${ }^{40}$

The Olifants River originates in an industrialized part of the province of Mpumulanga in South Africa, and it has been described as one of the most polluted rivers of southern Africa. ${ }^{1,19}$ It traverses Kruger National Park (KNP) from west to east and enters the Olifants Gorge $\left(23^{\circ} 98.850^{\prime} \mathrm{S}, 031^{\circ} 82.540^{\prime} \mathrm{E}\right)$ as it passes through the Lebombo Mountains before entering the Massingir Dam in Mozambique (Fig. 1).

In 2008, 2009, and 2010, between May and September, 208 Nile crocodiles were found dead in the Olifants River Gorge in KNP. ${ }^{11,47}$ Pansteatitis was diagnosed in fat stores from all 11 crocodiles submitted for histologic evaluation. A broad multidisciplinary research program is underway to investigate these events, including pathologic, nutritional, ecologic, toxicologic, and epidemiologic investigations of the crocodiles and fish prey species. This paper describes the pathologic findings in the somatic adipose tissue and the abdominal fat body of the affected crocodiles, and because postmortem findings in wild crocodilians in this remote portion of South Africa are not available. Information on additional lesions in other tissues is included. Possible causes of these lesions, and testing planned as part of the wider investigation, are briefly reviewed.

\section{MATERIALS AND METHODS}

In winter (May-August) 2008, high numbers (170) of dead Nile crocodiles were noted in the Olifants River Gorge in the KNP. ${ }^{11}$ The deaths subsided in the warmer summer (September 2008-April 2009) and recurred to a much lesser degree in winters 2009 (28 deaths) and 2010 (10 deaths). In 2011 and 2012, surveillance was limited by the need to assign resources to address significantly elevated rhinoceros poaching levels in KNP; however, four dead crocodiles were found in July 2011, with four additional carcasses in June-July 2012. Most of the 216 carcasses, and all of the crocodiles from which tissues were submitted for histologic examination were found in a 4-km stretch of the Olifants Gorge, along the South Africa-Mozambique border (Fig. 1).

The logistic challenges caused by the remote location of the gorge, which is only accessible by helicopter or foot; the drawn-out time frame of the investigation; the size of the reptiles concerned; and their aquatic habitat restricted disease investigations and led to inconsistencies in sample and data collection. Field postmortem examinations were conducted in 2008 (18 cases), 2009 (28 cases), and 2010 (10 cases). In severely decomposed carcasses, only the skin was incised to examine the fat, whereas more detailed postmortem examinations were performed on fresher carcasses (one in 2008 and two in 2009; Table 1). In addition, eight moribund crocodiles were culled by brain shot expressly for diagnostic purposes (three in 2008, two in 2009, and three in 2010). Because crocodile growth is continuous, 
Table 1. Crocodile identification number, sex, sexual maturity, body length, body condition, whether or not they were shot for necropsy purposes, and steatitis and related lesions for 11 crocodiles from the Olifants River Gorge (2008-2010).

\begin{tabular}{|c|c|c|c|c|c|c|c|c|c|c|c|}
\hline \multirow[t]{2}{*}{$\overline{\text { Finding }^{\wedge}}$} & \multicolumn{2}{|c|}{2008} & \multicolumn{6}{|c|}{2009} & \multicolumn{3}{|c|}{2010} \\
\hline & 1 & 2 & 3 & 4 & 1 & 2 & 3 & 4 & 1 & 2 & 3 \\
\hline Sex\# & $\mathrm{F}$ & M & & M & M & $\mathrm{F}$ & M & M & M & M & M \\
\hline Sexual maturity* & $\mathrm{A}$ & S & & A & $\mathrm{A}$ & A & S & A & $\mathrm{A}$ & A & A \\
\hline Body length (meters) & 3.0 & 2.0 & & 3.5 & 4.0 & 3.8 & 2.1 & & 3.8 & 4.2 & 3.4 \\
\hline Body condition** & 5 & 5 & & 5 & 5 & 5 & 2 & 1 & 2 & 2 & 1 \\
\hline Euthanized & + & + & - & + & - & - & + & + & + & + & + \\
\hline Autolysis*** & 2 & 2 & 3 & 1 & 5 & 5 & 1 & 1 & 1 & 1 & 1 \\
\hline Empty gastrointestinal tract & + & + & & + & + & + & + & & - & + & + \\
\hline Distended gall bladder & + & - & & + & + & + & + & & + & - & - \\
\hline Discoloured firm somatic fat & + & + & + & + & + & + & + & + & - & + & + \\
\hline Somatic fat steatitis & + & + & + & + & + & + & + & \pm & \pm & + & + \\
\hline Fat necrosis & + & + & + & + & + & + & + & - & - & + & - \\
\hline Granulomatous steatitis & + & + & + & + & + & + & + & + & + & + & + \\
\hline Vasculitis associated with steatitis & + & - & + & + & + & - & + & - & - & - & + \\
\hline Fat body steatitis & & & & - & + & + & + & & \pm & + & \pm \\
\hline Hepatic atrophy & + & + & + & - & + & - & - & + & - & - & + \\
\hline Hepatic hydropic degeneration & + & + & - & - & - & - & - & + & + & - & + \\
\hline Hepatic lipidosis & + & + & + & - & + & + & - & - & - & + & - \\
\hline Hepatic haemosiderosis/ceroid & + & + & + & + & + & + & + & - & + & + & + \\
\hline Splenic haemosiderosis/ceroid & + & + & & & & + & + & & + & + & + \\
\hline Renal tubular haemosiderosis/ceroid & + & & + & + & & + & + & + & + & & + \\
\hline Renal tubular hydropic degeneration & + & & + & + & & + & + & - & - & & - \\
\hline Renal tubular protein nephropathy & + & & + & + & & - & - & - & + & & + \\
\hline
\end{tabular}

Not examined/sampled

$\# \mathrm{~F}=$ female, $\mathrm{M}=$ male

$\mathrm{S}=$ subadult, $\mathrm{A}=$ adult

* Sexual maturity estimated from total length

* Condition was scored on subcutaneous, abdominal and fat body fat reserves using a scale of 1 (emaciated), 2 (poor), 3 (fair), 4 (good), 5 (excellent)

Autolysis was scored subjectively on histological appearance using a scale of 1 (none), 2 (minor), 3 (mild), 4 (moderate), 5 (severe) 


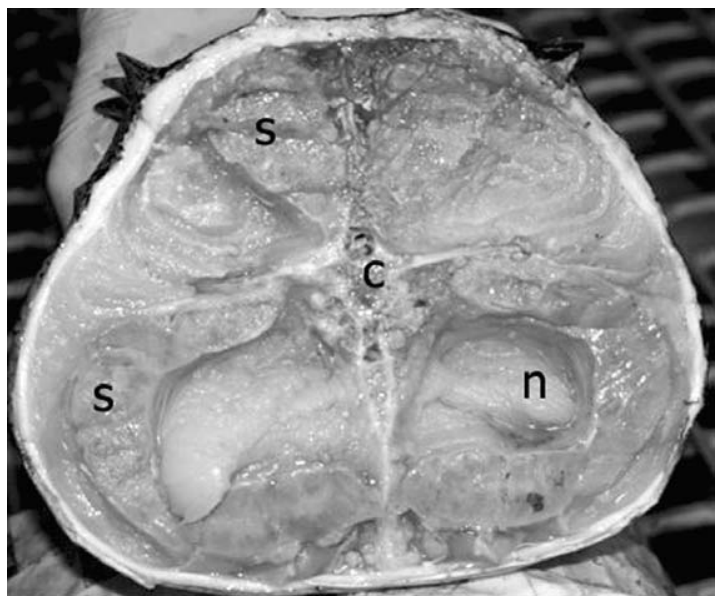

Figure 2. Nile crocodile steatitis. Cross section of the tail (c, caudal vertebra) with multiple orange, firm bilateral foci of steatitis (s) surrounded by normal fat (n).

depending on environmental temperatures, reproductive status, and food availability, and because sexual maturity cannot be reliably evaluated in males at necropsy, sexual maturity from total body length was estimated. ${ }^{26} \mathrm{~A}$ variable selection of tissues were collected from these 11 clinically affected crocodiles. These tissues were fixed in $10 \%$ buffered formalin and processed routinely. Samples were stained with hematoxylin and eosin, Ziehl Neelsen, Gram, Gomori's methamine silver, periodic acid shift, Perls' Prussian blue, and Gomori's aldehyde fuchsin.

\section{RESULTS}

\section{General findings}

Crocodile identification number, sex, sexual maturity, body length, body condition, whether

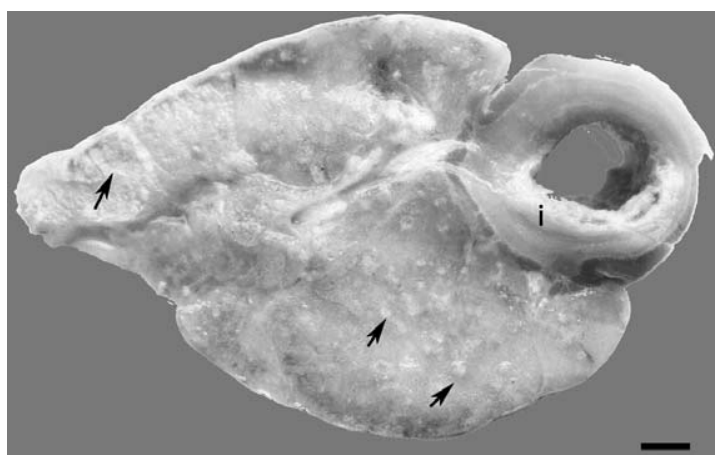

Figure 3. Nile crocodile steatitis. Multiple dark yellow-brown nodules (arrows) in the intestinal (i) visceral fat. $\mathrm{Bar}=5 \mathrm{~mm}$.

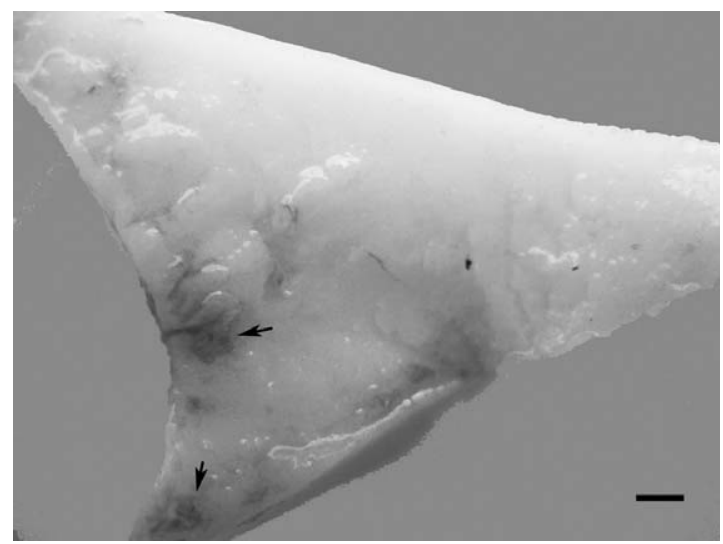

Figure 4. Nile crocodile steatitis. Rare small dark yellow-brown nodules (arrows) in the abdominal fat body. $\mathrm{Bar}=5 \mathrm{~mm}$.

or not they were shot for necropsy purposes, and key pathologic findings for the 11 crocodiles for which histology samples were collected are recorded in Table 1. Clinically affected crocodiles were found lying either in shallow water or on land, were lethargic and weak, and unwilling or unable to move either on land or in the water.

Five crocodiles examined in 2008 and 2009 were in excellent body condition, with ample subcutaneous, tail, and visceral fat deposits and large abdominal fat bodies. In 2009, one crocodile was in poor condition and the other was emaciated. In 2010, two crocodiles were in poor condition and the other two were emaciated, with marked muscle wasting. Findings that suggested inappetence included hepatic atrophy; an empty gastrointestinal tract, apart from a few gastroliths and intestinal mucus; a distended gall bladder; and marked pancreatic zymogen granular depletion (crocodile 2010-1).

\section{Steatitis and related lesions}

Subcutaneous, tail (Fig. 2), and visceral (Fig. 3) fat deposits from 10 of the 11 crocodiles were variably swollen, firm, nodular, and dark yellowbrown, or they contained multiple dark yellowbrown nodules within normal pale yellow fat tissue. Fat stores were macroscopically normal in crocodile 2010-1. Although the severity of the fat lesions was not evaluated macroscopically, subcutaneous neck fat subjectively appeared to be less affected than visceral fat; and the abdominal fat body, which was relatively small in comparison with the ample masses of somatic fat, was usually least affected, with often only a few, firm discolored nodules (Fig. 4). Affected adipose tissue 


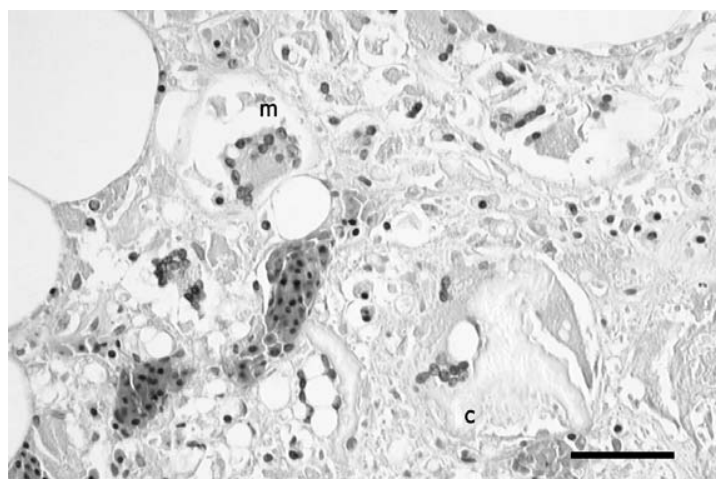

Figure 5. Nile crocodile steatitis. Granulomatous steatitis with multinucleate giant cells (m) associated with fat degeneration and necrosis, and ceroid pigment deposition (c). Hematoxylin and eosin stain. Bar $=50$ $\mu \mathrm{m}$.

surrounding the bifurcation of the trachea often obscured the associated endocrine glands.

All 11 crocodiles showed histologic adipose tissue lesions. In nine crocodiles, at least $75 \%$ of visceral fat showed saponification, degeneration, and necrosis characterized by loss of adipocyte cytoplasmic and nuclear definition, nuclear pyknosis and karyolysis, and replacement with amorphous pale pink intercellular material (interpreted as serum, degenerating fat, or both). Tracts of inflammation followed interlobular septae and serosal surfaces. Necrosis was associated with tracts and discrete coalescing foci of granulomatous inflammation consisting of foamy pink or pale yellow cellular debris and ceroid pigment, mixed with variable numbers of macrophages, histiocytes, rare erythrocytes, and occasional clusters of multinucleate giant cells (Fig. 5).

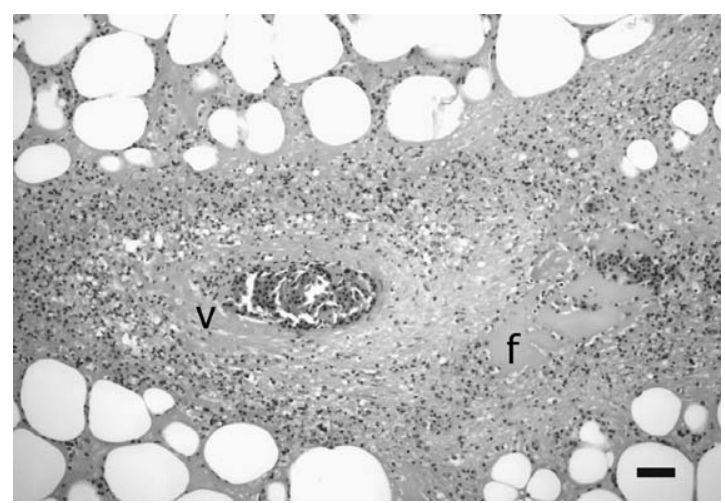

Figure 6. Nile crocodile steatitis. Necrotizing vasculitis (v) with perivascular fibrin deposition (f) and lymphoplasmacytic inflammation. Hematoxylin and eosin stain. Bar $=100 \mu \mathrm{m}$.

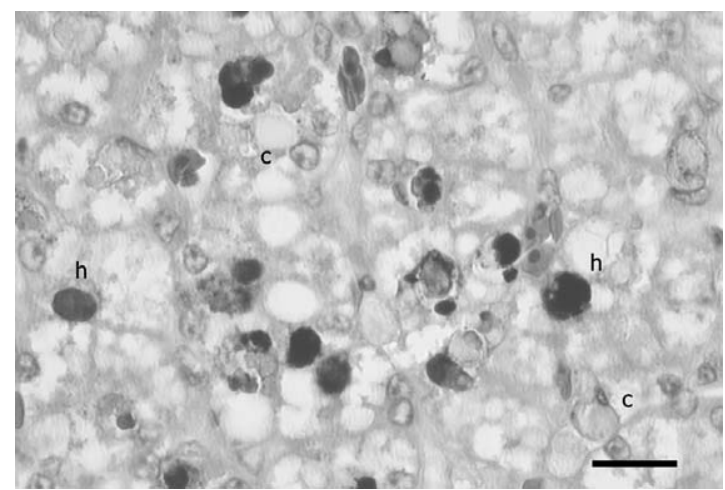

Figure 7. Nile crocodile hepatic pigment. Moderate amounts of hemosiderin (h) and ceroid or lipofuscin pigment (c) in the liver. Multiple discrete clear spaces represent moderate lipidosis. Hematoxylin and eosin stain. Bar $=20 \mu \mathrm{m}$.

Blood vessels in interlobular septae were congested. Arterioles in and adjacent to the fat showed variable tunica media hyaline degeneration and multifocal mainly lymphoplasmacytic but occasionally heterophilic periarteritis. Acute leukocytoclastic and necrotizing vasculitis with thrombosis and associated infarction of surrounding adipose tissue was present in six cases (Fig. 6). Crocodiles 2009-4 and 2010-1 showed much milder pansteatitis.

Livers were firm dark brown to grayish with large numbers of macrophages laden with hemosiderin, ceroid, or lipofuchsin or a combination of all these pigments (Fig. 7), variably associated with mild focal granulomatous lipid-associated hepatitis, hepatic lipidosis, and hydropic degeneration (Table 1). Splenic and renal hemosiderosis as well as renal protein nephropathy and hydropic degeneration was common (Table 1).

\section{Additional findings}

Four crocodiles had no other significant lesions apart from steatitis and related hepatic, splenic, and renal lesions (Table 1). Additional lesions that may have contributed to lethargy, weakness, or death are listed in Table 2. These lesions included moderately extensive external injuries attributed to bite wounds, postmortem scavenging by other crocodiles, or both (four crocodiles); marked ascites (four crocodiles); concurrent severe segmental acute necrotizing bacterial enteritis (three crocodiles); multifocal myocardial necrosis (three crocodiles); gastric ulceration with or without secondary bacterial gastritis (two crocodiles); mild hydropericardium 
Table 2. Additional findings in 11 crocodiles from the Olifants River Gorge (2008-2010).

\begin{tabular}{|c|c|c|c|c|c|c|c|c|c|c|c|}
\hline \multirow[t]{2}{*}{ Finding $\wedge$} & \multicolumn{3}{|c|}{2008} & \multicolumn{5}{|c|}{2009} & \multicolumn{3}{|c|}{2010} \\
\hline & 1 & 2 & 3 & 4 & 1 & 2 & 3 & 4 & 1 & 2 & 3 \\
\hline Recent external injuries & - & + & - & - & + & + & - & & - & + & - \\
\hline Ascites & - & - & - & + & + & + & + & & - & - & - \\
\hline Bacterial enteritis & - & - & - & - & + & + & + & - & - & - & - \\
\hline Myocardial degeneration/necrosis & - & + & - & + & - & - & - & - & + & - & - \\
\hline Gastric ulcers & - & - & & - & - & + & + & & - & - & - \\
\hline Skeletal muscle necrosis & & & & - & + & & - & - & - & - & - \\
\hline Liver abscess/splenitis & - & - & - & - & - & - & - & - & - & + & - \\
\hline Bacterial pneumonia & - & - & & - & - & - & - & + & - & - & - \\
\hline Hepatic melanomacrophage hyperplasia & - & + & + & + & - & + & - & + & - & - & - \\
\hline Hepatic myelopoeisis & + & - & + & - & - & - & + & + & - & - & - \\
\hline Subacute hepatitis & + & - & + & + & + & - & - & - & + & + & - \\
\hline Splenic budding & - & - & & - & + & - & - & 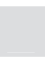 & + & - & + \\
\hline Splenomegaly & - & - & & - & & + & - & & + & + & + \\
\hline Splenic lymphoid hyperplasia & + & - & & - & & - & - & & - & - & - \\
\hline Hydropericardium & - & - & - & - & - & - & - & & - & + & + \\
\hline Epicardial tags & - & - & - & + & - & - & - & - & - & + & + \\
\hline Mild osteoarthritis & - & - & - & - & - & - & - & - & + & + & - \\
\hline Oral leeches & - & - & - & - & - & - & - & - & - & + & - \\
\hline Pulmonary pentostomes & - & - & - & - & - & + & - & - & + & - & - \\
\hline Verminous pneumonia & + & - & & - & + & - & - & - & - & - & + \\
\hline Verminous enteritis & - & - & & - & - & - & - & - & - & - & + \\
\hline Visceral coccidiosis & + & + & + & + & - & - & - & - & - & - & - \\
\hline Intestinal nematodes & - & - & & + & - & - & - & - & - & - & + \\
\hline Intestinal trematodes & - & + & & + & - & - & - & - & - & - & - \\
\hline
\end{tabular}

Not examined/sampled

with epicardial tags (two crocodiles); multifocal muscle necrosis (one crocodile); and a mixed bacterial and fungal hepatic abscess with acute splenitis (one crocodile). In addition, five crocodiles in 2009 and 2010 were in poor body condition or were emaciated.

A variety of incidental findings also were recorded (Table 2). Crocodile 2009-2 had moderate focal subacute lymphoplasmacytic tracheitis associated with a pentastome attachment site (Leiperia cincinnalis). Fragments of Micropleura sp. nematodes were extracted from the lung of crocodile 2009-4. A few large unidentified helminths were found loose in the abdominal cavity or encapsulated under the peritoneum of the viscera. Mild periarteriolar lymphoid tissue hyperplasia, variably associated with sporulated coccidian oocysts, containing four sporocysts, occurred in numerous organs in all crocodiles with minimal or mild lymphoplasmacytic and heterophilic inflammation. 


\section{DISCUSSION}

\section{General findings}

The macroscopic and histologic appearance of the tissues from these crocodiles is consistent with a diagnosis of pansteatitis, as recorded previously in chelonians ${ }^{43}$ and crocodilians. ${ }^{11,26,29,36,39,45,51,62}$ Ceroid pigment, lipofuscin pigment, or both in macrophages in liver, spleen, and kidney as well as in fat was recorded in nutritional panniculitis in domestic cats, swine, foals, and mink. ${ }^{16}$ Ceroid is considered the early stage of fatty acid oxidation and is thought to trigger the inflammatory response. The final product is lipofuscin, an insoluble product of the polymerization of peroxides of unsaturated fatty acids with lipoproteins that is responsible for the typical yellow discoloration of the adipose tissue. ${ }^{8,29,52}$

The reason why mainly adult male crocodiles were affected is obscure. Detection of carcasses in the wild depends at least in part on carcass size and the rate at which carcasses are removed by scavengers and other ecologic disposal mechanisms. ${ }^{63}$ Smaller male or female crocodiles that drowned during these mortality events, for example, may have gone uncounted. Spatial river use and diet also may differ between males and females. Endocrine disrupting chemicals are being analyzed in the water and sediments to investigate the possible role of testosterone in the development of steatitis.

\section{Cause of death}

Evaluation of the cause of lethargy or death was hampered by submission of only selected tissues from each crocodile carcass and by the lack of reported or archived information on common conditions present in free-ranging crocodiles. Death in crocodiles with steatitis has been previously attributed to starvation and exposure. ${ }^{26}$ Smaller numbers of dead crocodiles were noted in 2009 and 2010, and examined crocodiles had marked muscle wasting, compared with the crocodiles in 2008 that were in excellent body condition. Five of the six crocodiles from the 2009-2010 cohort for which gastrointestinal content was noted had empty gastrointestinal tracts. Their somatic and fat body fat stores were reduced, but five of the seven crocodiles still had significant steatitis, often without the necrosis seen in earlier cases. Although how long ceroid and lipofuscin pigment remains in the fat is unknown, this finding suggests that an initial incident occurred in 2008 in which severely affected crocodiles died acutely, whereas less severely affected crocodiles survived the initial incident but incurred sufficient damage to the fat stores that led eventually to their death due to starvation and or cannibalism.

Crocodiles have two different types of fat stores: somatic and metabolic. "Somatic" fat is found under the neck and abdominal skin in adult crocodiles, as well as between the tail muscles, under the peritoneum, in the mesentery, and in the thorax surrounding the trachea. "Metabolic" fat is found in the abdominal fat body and is more readily accessible than somatic fat. ${ }^{26}$ Steatitis likely renders stored fat metabolically unavailable. Because inflammation was usually much milder in the abdominal fat body than in somatic fat, crocodiles with large fat bodies, despite extensive somatic fat lesions (in 2008 and 2009), likely had accessible nutritional reserves and death was caused by other factors. ${ }^{26}$

Steatitis alone appeared to be the cause of death in one of the three crocodiles found dead and in three crocodiles shot for necropsy purposes. Somatic fat steatitis, particularly between the muscles of the tail, was likely at least in part responsible for the inability or unwillingness of the crocodiles to swim, perhaps due to pain, mechanical compression of the musculature, loss of normal adipose flexibility, or a combination of these factors. ${ }^{26}$ However, death was likely to have been multifactorial, at least in some cases, because at least mild steatitis may occur in apparently healthy crocodiles, ${ }^{39}$ and crocodiles $2009-4$ and 2010-1 had minimal steatitis despite clinical signs that resembled those shown by crocodiles with steatitis.

In farmed Cuban crocodiles suffering from pansteatitis, ${ }^{45}$ vitamin E-deficient fish, ${ }^{23,56}$ and terrestrial mammals, $, 9,93,34,42,52$ hyaline leg muscle degeneration was thought to be an additional reason for the animals' inability to move. Myocardial necrosis was present in 3 of the 11 crocodiles, and skeletal muscle necrosis was present in one of the six crocodiles where muscle was sampled (Table 1). Heart failure, muscle necrosis, or both may therefore partially account for the lethargy noted. Crocodiles sampled in 2008 showed significant hypocalcemia compared with free-ranging crocodiles, a condition that also may have contributed to the lethargy. ${ }^{4}$

Concurrent acute bacterial gastroenteritis, fungal gastroenteritis, or both; hepatitis; or pneumonia likely significantly affected health status in six crocodiles. Whether these infections were primary infections ${ }^{30,31}$ or secondary to compromised immunity or altered intestinal flora as a result of 
stress, compromised thermoregulation, inappetence, or secondary to external injuries (seen in four crocodiles ${ }^{26,27}$ is uncertain. These infections, as well as nonspecific subacute tissue inflammation and parasite infestations, likely account for the splenomegaly (seen in four crocodiles) and the splenic capsular "buds" (seen in three crocodiles), a sign of an activated system immune response in crocodiles. $^{26}$

Intestinal obstruction and altered intestinal motility due to mesenteric fat necrosis may have occurred as described in cattle. ${ }^{6}$ The pathogenesis of ascites and hydropericardium is uncertain, because it was not clearly related to poor body condition (hypoproteinemia), external injuries, systemic infectious disease, or myocardial necrosis. Acute heart failure may have played a role. Hepatic atrophy and lipidosis may have been due to starvation, hypertriglyceridemia, or both and oxidative lipolysis may have been due to anorexia and fat necrosis.

\section{Pathogenesis}

Steatitis commonly results from an altered balance between oxidants, such as high levels of dietary unsaturated fatty acids, trophic accumulation of oxidants, or both, and the levels of antioxidants. ${ }^{14,17,29}$ Dietary deficiencies of selenium and vitamin $\mathrm{E}$ have been implicated in the development of steatitis in fish and reptiles. $^{21,23,38,44,45}$ Ingestion of fish suffering from steatitis could account for the crocodile steatitis. Sharptooth catfish (Clarias gariepinus) are a common component of Nile crocodile diets, ${ }^{61}$ and many of the larger specimens of these fish in the Olifants River Gorge had similar steatitis. ${ }^{28}$ However, only minimal differences in fatty acid profiles were found between affected and noninfected crocodiles, ${ }^{50}$ in contrast to those recorded in experimentally induced steatitis in cats. ${ }^{14} \mathrm{In}$ addition, many of these large catfish in the gorge, had fish remnants in their stomachs, compared with vegetable or invertebrate content in the stomachs of catfish from other waters where steatitis was not present. These findings suggest that the catfish were either preying on other weakened fish or scavenging off dead fish in the gorge. ${ }^{28}$ Stable isotope analysis is underway to evaluate the relative trophic levels of the fish and crocodiles to investigate whether they are affected through a common dietary source.

Apart from a diet high in oxidized unsaturated fat, abnormal dietary levels of other oxidants may be relevant, because high iron intake in sharptooth catfish caused poor growth and high lipid peroxidation products and depleted $\alpha$-tocopherol stores. $^{3}$ Vasculitis associated with the steatitis could be an indication of infectious or immunemediated disease; however, vasculitis is a feature of hepatosis dietetica in pigs, which is due to combined deficiencies of sulfur-rich amino acids, vitamin $\mathrm{E}$, and selenium. ${ }^{6,8}$

Tissue selenium and vitamin E levels are being tested. The typical mineralization and multiphasic muscle damage seen in domestic animals with vitamin $\mathrm{E}$ deficiency also was not present in these crocodiles, but typical lesions may have been missed because no leg muscles were sampled in this series. In crocodiles, degenerative brain lesions similar to those of encephalomalacia in chicks occur in hypovitaminosis E. ${ }^{45}$ In the present study, no brains were sampled; for humane reasons, the live animals were killed by a gunshot to the brain. Diseases such as enteritis that may affect absorption of needed antioxidants also may cause steatitis, ${ }^{14,59}$ but no such disease was noted in these crocodiles.

Low and fluctuating ambient temperatures play a role in the development of steatitis in vitamin Edeficient fish ${ }^{55}$ and crocodiles. ${ }^{11,45,62}$ Poikilothermic animals depend on lipoprotein and polyunsaturated fats to maintain membrane fluidity and normal metabolic function. They are thus likely to be more sensitive to the effects of lipid oxidation at lower ambient temperatures because temperature-dependent metabolic rates affect oxidative pathways. ${ }^{25,57}$ Annual mortality events (20082009) were closely related to winter minimum temperatures at a nearby weather station (Letaba), with mortalities starting in mid-May, peaking in mid-July, and tailing off by mid-September (Fig. 8). Temperature records for subsequent years are currently not available. Steatitis-related immobility also could have impaired normal behavioral thermoregulation. ${ }^{18}$

Additional factors such as pollution have been suggested as a possible cause of the fish and crocodile mortalities in the Olifants River because it is known to be a highly polluted river, ${ }^{1}$ and a large multispecies die-off occurred approximately $300 \mathrm{~km}$ upstream in the Loskop Dam in 2007 after a release of acid mine water effluent into the river. ${ }^{10,47}$ Toxins have been implicated in the pathogenesis of steatitis in ruminants, ${ }^{58} \mathrm{fish},{ }^{55}$ and birds. ${ }^{10,43,47,48}$ Testing of pollutant levels in the water and crocodile tissues is underway, as well as testing in waters and crocodile tissues from unaffected rivers for comparison. Evaluation of direct, additive, and synergistic effects of pollutants is planned. 


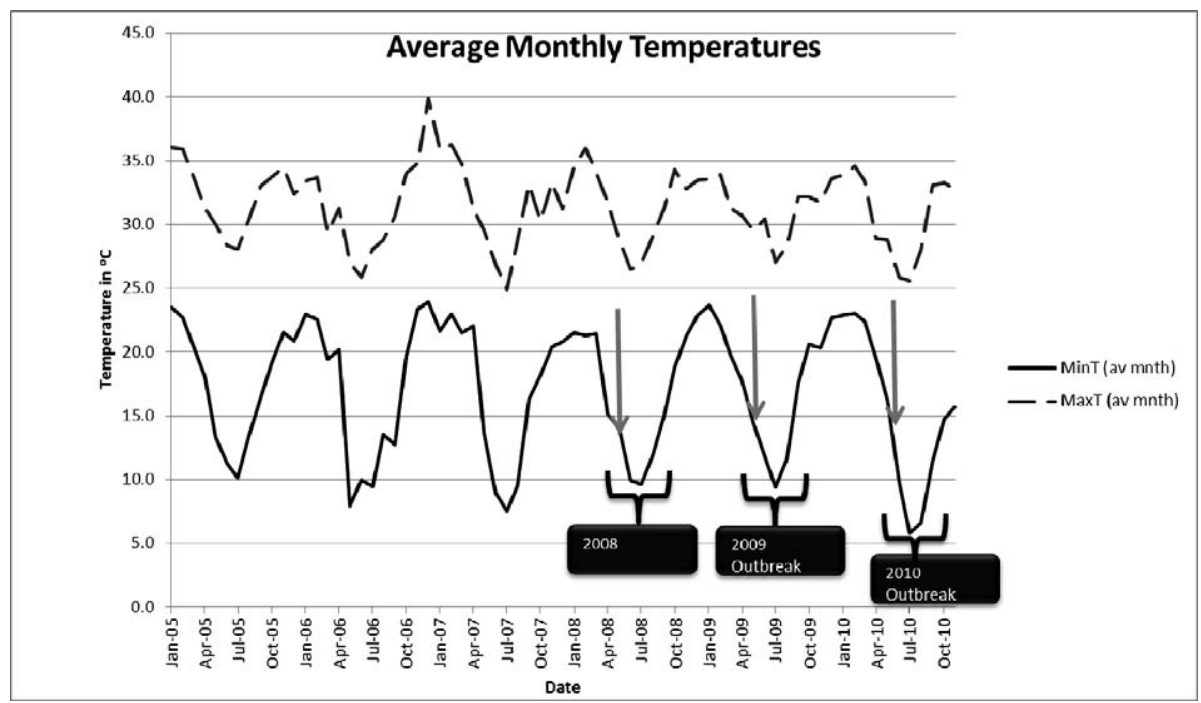

Figure 8. Average maximum and minimum monthly temperatures (2005-2010) at the closest weather station to the Olifants River Gorge (Letaba, Kruger National Park) with the onset of crocodile mortalities (gray arrows).

Several simultaneous changes occurred in the Olifants River Gorge in 2008. One change involved increased river flow rates due to unusually heavy rains and the raising of sluice gate levels at the downstream Massingir Dam in Mozambique, leading to flooding of the gorge, associated progressive eutrophication and blue-green algae (cyanobacteria) blooms, and a buildup of fine clay sediments in the areas favored by the crocodiles. But whether these changes resulted in altered exposure to pollutants, caused stress, or altered activity patterns that triggered an oxidant imbalance $^{7,8,44}$ is uncertain. Sharptooth catfish from the Olifants Gorge had more clay sediments in their intestines than those from waters where the fish do not have steatitis. ${ }^{28}$ Sediments in the flooded gorge may concentrate pollutants to which fish and crocodiles are then exposed. The last recorded mass mortality of fish in the Olifants Gorge occurred $27 \mathrm{yr}$ earlier after the release of silt into the river (Venter, pers. comm.). This mass mortality involved various species of fish and was not associated with crocodile mortalities, possibly because the widespread and even distribution of dead fish throughout the Olifants River allowed for rapid consumption by various scavengers.

The cyanobacterial bloom that developed at the inlet of the Massingir Dam may be significant. Liver levels of microcystin toxin are being determined. Typical hepatic necrosis seen in mammalian cases of algae microcystin toxicity ${ }^{20}$ was not present in these crocodiles, although species differences in susceptibility and tissue responses to this toxin may occur. In addition, cyanobacteria produce a variety of toxins, the effects of some of which are not well characterized. ${ }^{48}$

Mice with Coxsackie virus infection may develop steatitis; ${ }^{22}$ however, no infectious agents have been found on light microscopy in association with the lesions in these crocodiles, thus their role is uncertain. Pericarditis and epicarditis may result, in crocodiles, from septicemia and $\mathrm{Myco}$ plasma infection; ${ }^{27}$ epicarditis was found in only two crocodiles and the lesions were chronic, with no indication of a possible cause at the time of death or relationship to the development of steatitis.

\section{Incidental findings}

Mild nonspecific hepatic melanophage hyperplasia, myelopoiesis, and periportal hepatitis as well as mildly reactive spleens are likely within normal range for free-ranging crocodiles. Nile crocodile coccidia have not yet been named, with the exception of Goussia sp. that is characterized by the presence of sporulated oocysts in intestine and other organs, as found in the present material. ${ }^{15}$ The cross-sectioned nematode larvae in the stomach of crocodile 2009-3 resembled Crocodilocapillaria longiovata, a species that has been described from crocodiles in Australia and New Guinea. ${ }^{46}$ Similar nematodes have been found in the gastric glands of wild-caught African dwarf crocodiles (Osteolaemus tetraspis). ${ }^{26}$ The nema- 
todes found free in the abdominal cavity or under the serosa were not submitted for identification but most likely were Filariae, for example, Oswaldofilaria vesterae, a species known from Nile crocodiles in South Africa. ${ }^{2}$ An absence of Paratrichosoma trails noted in the skins might be linked to the disturbed ecosystem, affecting the survival of invertebrate intermediate hosts. Many species of digenetic trematodes are found in Nile crocodiles, but they cannot be identified from cross sections in histopathologic specimens. ${ }^{26}$ Pentastomes belonging to genera Leiperia, Sebeki, and Alofia have been found in Nile crocodiles in KNP; they all use fish as intermediate hosts. ${ }^{35}$

\section{CONCLUSIONS}

No previous mortality event affecting the crocodile in KNP is on record. The cause or causes of the steatitis in Nile crocodiles and sharptooth catfish in the Olifants River Gorge have not yet been established. Reduced mortality each year and decreasing nutritional condition in affected crocodiles suggest that an initial incident occurred in 2008 with long-standing effects on the crocodile population. The role of infectious agents, vitamin $\mathrm{E}$ or selenium deficiency, exposure to pollutants or cyanobacterial toxins, the health and diet of catfish on the Olifants River Gorge, the ecologic role played by alien invasive filter-feeding silver carp (Hypophthalmichthys molitrix), and the health status in human users of the lower Olifants River system are the subject of a broad multidisciplinary research program supervised by SANParks. The passage of time, the exit of polluted water from the river system, and the complexity of the anthropogenic factors affecting this river will likely hamper the investigation. Crocodiles are apex predators in an aquatic environment that also is used by humans upstream and downstream from KNP for water collection, fishing, and recreation. Crocodiles in this scenario are thought to play a similar role to raptors affected by 1,1,1-trichloro-2,2-di(4-chlorophenyl)ethane (DDT), by alerting scientists and policy makers to anthropogenic environmental changes that may have far reaching effects on domestic animal, wildlife, and human health.

Acknowledgments: Histopathologic processing was funded by the U.S. Fish and Wildlife Service. We are indebted to the histopathology labs of the National Health Laboratory Service (Gauteng) and the Pathology Section of the Department of Paraclinical Sciences of the Faculty of Veterinary Science, University of Pretoria, for excellent technical assistance. SANParks helicopter pilots
Grant Knight and Charles Thompson flew the Olifants Gorge to find and recover dead crocodiles. Olifants Section Ranger Evans Mkansi and staff worked in difficult field conditions, patrolling, recovering, and burning carcasses and recording mortalities. SANParks staff Jenny Joubert, Khosi Maseko, and Purvance Shikwabana, as well as Paolo Martelli from Oceanpark (Hong Kong), Rolando Queseda, Karen van Rooyen, Louis le Grange, and Magali Chabrolles assisted in the collection and processing of samples. Dr. Kerstin Junker, Onderstepoort Veterinary Institute, identified the parasites named in the paper. Sandra MacFadyen, GIS Laboratory, SANParks, produced the GIS map of the study area.

\section{LITERATURE CITED}

1. Ashton, P. J. 2010. The demise of the Nile crocodile (Crocodylus niloticus) as a keystone species for aquatic ecosystem conservation in South Africa: the case of the Olifants River. Aquat. Conserv. Mar. Freshw. Ecosyst. 20: 489-493.

2. Bain, O., B. Kouyaté, and M. Baker. 1982. Nouvelles données sur les Oswaldofilariinae (Filaroidea, Nematoda). Bull. Mus. Nat. Paris 4A: 61-69.

3. Baker, R. T., P. Martin, and S. J. Davies. 1997. Ingestion of sub-lethal levels of iron sulphate by African catfish affects growth and tissue lipid peroxidation. Aquat. Toxicol. 40: 51-61.

4. Botha, P. L. 2010. The distribution, conservation status and blood biochemistry of Nile crocodiles in the Olifants river system, Mpumalanga, South Africa. Ph.D. thesis, University of Pretoria, South Africa.

5. Brooks, H. V., C. G. Rammell, J. J. L. Hoogenboom, and D. E. S. Taylor. 1985. Observations on an outbreak of nutritional steatitis (yellow fat disease) in fitch (Mustella putorius furo). N Z Vet. J. 33: 141-145.

6. Brown, C. C., D. C. Baker, and I. K Barker. 2007. Alimentary system. In: Maxie, M. G. (ed.). Jubb, Kennedy, and Palmer's Pathology of Domestic Animals, vol. 2, 5th ed. Saunders Elsevier, Edinburgh, United Kingdom. Pp. 285-286.

7. Brush, P. J., and P. H. Anderson. 1986. Levels of plasma alpha-tocopherol (vitamin E) in zoo animals. Int. Zoo Yearb. 24/25: 316-321.

8. Danse, L. H. J. C., and W. A. SteenbergenBotterweg. 1974. Enzyme histochemical studies of adipose tissue in porcine yellow fat disease. Vet. Pathol. 11: 465-476.

9. Dixon, R. J., W. O. Nuttall, and D. A. Carthew. 1983. A case of steatitis and myonecrosis in a donkey foal. N Z Vet. J. 31: 62.

10. Dreischer, A. C. 2008. A water quality study of Loskop Dam and the upper catchment of the Olifants River. M. Sc. thesis, University of the Free State, Bloemfontein, South Africa. 
11. Ferreira, S. M., and D. Pienaar. 2011 Degradation of the crocodile population in the Olifants River Gorge of Kruger National Park, South Africa. Aquat. Conserv. Mar. Freshw. Ecosyst. 21: 155-164.

12. Foggin, C. M., 1992. Diseases of farmed crocodiles. In: Smith, G. A., and J. Marais (eds.). Conservation and Utilization of the Nile Crocodile in Southern Africa. The Crocodile Study Group of Southern Africa, Pretoria, South Africa. Pp. 107-140.

13. Foreman, J. H., K. A. Potter, W. M. Bayly, and H. D. Liggitt. 1986. Generalised steatitis associated with Selenium deficiency and normal vitamin E status in a foal. J. Am. Vet. Med. Assoc. 189: 83-86.

14. Fytianou, A., A. F. Koutinas, M. N. Saridomichelakis, and C. K. Koutinas. 2006. Blood $\alpha$-tocopherol, selenium and glutathione peroxidase changes in kittens with experimental steatitis (yellow fat disease). Biol. Trace Elem. Res. 112: 131-143.

15. Gardiner, C. H., G. D. Imes, E. R. Jacobson, and C. M. Foggin. 1986. Sporulated coccidian oocysts resembling Goussia Labbe, 1896 in the viscera of Nile crocodiles. J. Wildl. Dis. 22: 575-577.

16. Ginn, P. E., J. E. K. L. Mansell, and P. M. Rakich. 2007. Skin and appendages. In: Maxie, M. G. (ed.). Jubb, Kennedy, and Palmer's Pathology of Domestic Animals, 5th ed., vol. 1. Saunders Elsevier, Edinburgh, United Kingdom. P. 553-781.

17. Goodwin, A. E. 2006. Steatitis, fin loss and skin ulcers of channel catfish, Ictalurus punctatus (Rafinesque), fingerlings fed salmonid diets. J. Fish Dis. 29: 61-64.

18. Grigg, G. C., F. Seebacher, L. A. Beard, and D. Morris. 1998. Thermal relations of large crocodiles, Crocodylus porosus, free-ranging in a naturalistic situation. Proc. R. Soc. Lond. B 265: 1793-1799.

19. Grobler, D. C., P. L. Kempster, and L. van der Merwe. 1994. A note on the occurrence of metals in the Olifants River, Eastern Transvaal, South Africa. Water SA 20: 195-205.

20. Guzman, R. E., and P. F. Solter. 2002. Characterization of sublethal microcystin-LR exposure in mice. Vet. Pathol. 39: 17-26.

21. Halver, J. E. 2002. The vitamins. In: Halver, J. E., and R. W. Hardy (eds.). Fish Nutrition. Academic Press, Amsterdam, The Netherlands. Pp. 122-124.

22. Hashimoto, I., M. Tomita, T. Kohara, I. Unchino, and A. Harasima. 1985. Steatitis in mice infected with Coxsackie virus B3. Microbiol. Immunol. 29: 371-376.

23. Helder, T. 1979. Myopathy and steatitis in the common guppy, Poecilia (Lebistes) reticulata (Peters). Lab Anim. 13: 225-226.

24. Herman, R. L., and F. W. Kircheis. 1985. Steatitis in Sunapee trout, Salvelinus alpinus oquassa Girard. J. Fish Dis. 8: 237-239.

25. Hermes-Lima, M., C. Careirro, D. C. Moreira, C. Polcheira, D. P. Machado, and E. G. Campos. 2012. Glutathione status and antioxidant enzymes in a crocodilian species from the swamps of the Brazilian Pantanal. Comp. Biochem. Physiol. A 163: 189-198.

26. Huchzermeyer, F. W. 2003. Crocodiles: Biology, Husbandry and Diseases. CABI Publishing, Wallingford, United Kingdom. Pp. 28-35.

27. Huchzermeyer, F. W., M. M. Henton, J. Riley, and M. Agnagna. 2000. Aerobic intestinal flora of wildcaught African dwarf crocodiles, Osteolaemus tetraspis. Ond. J. Vet. Res. 67: 201-204.

28. Huchzermeyer, K. D. A., D. Govender, D. J. Pienaar, and A. R. Deacon. 2011. Steatitis in wild sharptooth catfish, Clarias gariepinus (Burchell), in the Olifants and Lower Letaba rivers in the Kruger National Park, South Africa. J. Fish Dis. 34: 489-498.

29. Jacobsen, E. R. 1984. Immobilization, blood sampling and necropsy techniques and diseases of crocodilians: a review. J. Zoo Anim. Med. 15: 38-45.

30. Jacobsen, E. R. 2007. Bacterial diseases of reptiles. In: Infectious Diseases and Pathology of Reptiles. Taylor \& Francis, London, United Kingdom. P. 461-526.

31. Jacobsen, E. R. 2007. Mycotic diseases of reptiles. In: Infectious Diseases and Pathology of Reptiles. Taylor \& Francis, London, United Kingdom. Pp. 527-531.

32. Jacobsen, N. H. G. 1998. The Nile crocodile. In: South African Red Data Book-reptiles and amphibians. South African National Scientific Programmes Report No. 151. Branch, W. R. (eds.). CSIR, Pretoria, South Africa.

33. Juan-Sallés, C., N. Prats, A. Resendes, M. Domingo, D. Hilton, J. M. Ruiz, M. M. Garner, X. Valls, and A. J. Marco. 2003. Anemia, myopathy, and pansteatitis in vitamin E-deficient captive marmosets (Callithrix spp.). Vet. Pathol. 40: 540-543.

34. Juan-Sallés, C., N. Prats, J. M. Ruiz, X. Valls, J. Gine, M. M. Garner, J. Verges, and A. J. Marco. 2000. Antioxidant status in a squirrel monkey (Saimiri sciureus) with chronic pancreatitis and degenerative myopathy. J. Comp. Pathol. 123: 202-206.

35. Junker, K., J. Boomker, and L. A. Bolton. 1999. Pentastomid infections in Nile crocodiles (Crocodylus niloticus) in the Kruger National Park, South Africa, with a description of the males of Alofia simpsoni. Ond. J. Vet. Res. 66: 65-71.

36. Ladds, P. W., H. Mangunwirjo, D. Sebayang, and P. W. Daniels. 1995. Diseases of young farmed crocodiles in Irian Jaya. Vet. Rec. 136: 121-124.

37. Lall, S. P. 2002. The minerals. In: Halver, J. E., and R. W. Hardy (eds.). Fish Nutrition. Academic Press, Amsterdam, The Netherlands. Pp. 259-298.

38. Lance, V. A., L. A. Morici, R. M. Elsey, E. D. Lund, and A. R. Place. 2001. Hyperlipidemia and reproductive failure in captive reared alligators: vitamin E, vitamin A, plasma lipids, fatty acids, and steroid hormones. Comp. Biochem. Physiol. B 128: 285-294.

39. Larson, R. E., C. Buergelt, P. T. Cardeilhac, and E. R. Jacobsen. 1983. Steatitis and fat necrosis in 
captive alligators. J. Am. Vet. Med. Assoc. 183: 12021204.

40. Levite, H., H. Sally, and J. Cour. 2003. Testing water demand management scenarios in a waterstressed basin in South Africa: application of the WEAP model. Phys. Chem. Earth 28: 779-786.

41. Lohr, J. E., and R. D. McLaren. 1971. "Yellow fat disease" (pansteatitis) in wild hares in New Zealand. N Z Vet. J. 19: 266-269.

42. Menzies-Gow, N. J., J. C. Patterson-Kane, and C. M. McGowan. 2002. Chronic nodular panniculitis in a 3-year old mare. Vet. Rec. 151: 416-419.

43. Mettler, F., and B. Hauser. 1979. Spontane yellow fat disease (steatitis) bei zwei schmuckschildkröten. Erkrankungen der Zootiere. Verhandlungsbericht des XXI. Internationalen Symposiums, Mulhouse: 145-146.

44. Miller, D. L., and J. L. Weisman. 2006. Lipoid liver disease and steatitis in a captive sapphire damsel, Pomacentrus pavo. Acta Ichthol. Piscat. 36: 99-104.

45. Moliner, J. L., R. Ramos, O. Bello, and S. Elizalde. 2000. Consideraciones clinicas y anatomopatologicas en la deficiencia de vitamina $\mathrm{E}$ (esteatitis) en el cocodrilo cubano (Crocodylus rhombifer) del Zoocriadero de la Cienaga de Zapata, Matanzas, Cuba. In: Crocodiles. Proc. 15th Working Meeting of the Crocodile Specialist Group, IUCN. The World Conservation Union, Gland, Switzerland, and Cambridge, United Kingdom: 118-123.

46. Moravec, F., and D. M. Spratt. 1998. Crocodilocapillaria longiovata n. gen., n. sp. (Nematoda: Capillariidae) from the stomach of crocodiles in Australia and New Guinea. J. Parasitol. 84: 426-430.

47. Myburgh, J., and A. Botha. 2009. Decline in herons along the lower Olifants River-could pansteatitis be a contributing factor? Vet. News 3: 20-23.

48. Neagari, Y., S. Arii, M. Udagawa, M. Onuma, Y. Odaya, T. Kawasaki, M. Tenpaku, H. Hayama, K. Harada, M. Misukami, and K. Murata. 2011. Steatitis in egrets and herons from Japan. J. Wildl. Dis. 47: 4955 .

49. Niza, M. M. R. E., C. L. Vllela, and L. M. A. Ferreira. 2003. Feline pansteatitis revisited: hazards of unbalanced home made diets. J. Feline Med. Surg. 5: 271-277.

50. Osthoff, G., A. Hugo, H. Bouwman, P. Buss, D. Govender, C. C. Joubert, and J. C. Swarts. 2010. Comparison of the lipid properties of captive, healthy wild and pansteatitis-affected wild Nile crocodiles (Crocodylus niloticus). Comp. Biochem. Physiol. A 155: 64-69.
51. Ousavaplangchai, L., J. Tangtrongpiros, and S. Pitchayankul. 1990. Steatitis in freshwater crocodiles (Crocodilus siamensis). Proc. 7th Congress of the Federation of Asian Veterinary Associations, Chonburi, Thailand: 615-619.

52. Platt, H., and K. E. Whitwell. 1971. Clinical and pathological observations on generalised steatitis in foals. J. Comp. Pathol. 81: 499-508.

53. Pollack, C. G., J. M. Sleeman, C. D. Houle, and E. C. Ramsay. 1999. Vitamin E deficiency and pansteatitis in juvenile boat-billed herons (Cochlearius cochlearius). J. Zoo Wildl. Med. 30: 297-300.

54. Rattner, A. B., and C. P. McGowan. 2007. Potential hazards of environmental contaminants to avifauna residing in the Chesapeake Bay estuary. Waterbirds 30: 63-81.

55. Roberts, R. J. (ed.). 2004. Fish Pathology, 3rd ed. W. B. Saunders Co., Edinburgh, United Kingdom. Pp. 352-354.

56. Roberts, R. J., and C. Agius. 2008. Pan-steatitis in farmed northern bluefin tuna, Thunnus thunnus (L.), in the eastern Adriatic. J. Fish Dis. 31: 83-88.

57. Seebacher, F., S. A. Murray, and P. L. Else. 2009. Thermal acclimation and regulation of metabolism in a reptile (Crocodylus porosus): the importance of transcriptional mechanisms and membrane composition. Physiol. Biochem. Zool. 82: 766-775.

58. Smith, G. W., D. S. Rotstein, and C. F. Brownie. 2004. Abdominal fat necrosis in a pygmy goat associated with fescue toxicosis. J. Vet. Diag. Invest. 16: 356359.

59. Stalker, M. J., and M. A. Hayes. 2007. Liver and biliary system. In: Maxie, M. G. (ed.). Jubb, Kennedy, and Palmer's Pathology of Domestic Animals, 5th ed., vol. 2. Elsevier Saunders, Edinburgh, United Kingdom. P. 297-388.

60. Wagner, J. E., and D. R. Dietlein. 1970. Steatitis in an American white pelican. Int. Zoo. Yearb. 10: 174.

61. Wallace, K. M., and A. J. Leslie. 2008. The diet of the Nile crocodile (Crocodylus niloticus) in the Okavango Delta, Botswana. J. Herpol. 42: 361-368.

62. Wallach, J. D., and C. Hoessle. 1968. Steatitis in captive crocodilians. J. Am. Vet. Med. Assoc. 153: 845847 .

63. Woebeser, G. A. 2006. Essentials of Disease in Wild Animals. Blackwell Publishing, Ames, Iowa. Pp. 45-46.

Received for publication 6 November 2012 